\title{
The Use of Annual Financial Statements by Loans Officers in Kenya
}

\author{
Adam Mohammed Boru \\ Central Bank Of Kenya, Box 60000-00200, Nairobi, Kenya. \\ Otieno Odhiambo Luther \\ Department of Finance and Accounting, University Of Nairobi, \\ P.O. Box 30197, Nairobi 00100 Kenya
}

\begin{abstract}
In Kenya, the incidence of bad loans is worrying and this put to question the credit models and quality of information employed by credit analyst. A possible explanation could be the quality of information contained in annual reports. Loan managers use financial statements in deciding to grant a loan, the amount to lend, the rate of interest rate and the other details to incorporate in the loan (bond) covenant. Stephens (1980) revealed that half of bank lending officers would refuse to loan to a company that did not submit financial statements, even though explicitly requested. The findings reported in the papers were based on evidence obtained from a survey. A structured questionnaire consisting of closed-ended questions is administered to all credit analysts in commercial banks in Kenya. At the time of the study, there were 43 commercial banks in total. The questionnaire covered: Lending objectives; Sources of information; Level of reading of different sections of financial statements; Additional information to be included in financial statements; Additional information to be incorporated in the Company's Act; and Background Information. The findings show that financial statements are rated as a very important source of information by credit risk analysts. However, commercial banks do not rely on one source of information. Customer records with the commercial bank, visits to customer premises and customer project proposals were also ranked as a very important source of information. The worry is evidence of lack for concern about social objectives when lending. Social justice and politics are core tenets of corporate governance. Credit risk analysts are not satisfied with the current financial disclosure levels in the company act. They would like potential borrowers to disclose a change in top management, cash flow statement, turnover, profit forecast and sales forecast in annual report. There is a need to review the company's act.
\end{abstract}

Keywords: Commercial Banks; Financial Statements; and Company's Act

DOI: $10.7176 /$ RJFA/11-8-15

Publication date: April $30^{\text {th }} 2020$

\section{Introduction, Justification for the Study}

Firms in emerging markets are heavily reliant on commercial banks for their capital requirement because stock markets and bond markets are not as developed as they are in developed countries (World Economic Forum Report, 2015). On the importance of accounting data, Lev and Ohlson (1982) assert that, "Accounting data convey useful and timely information to investors. While this conclusion definitely holds for earnings data, the marginal contribution of the voluminous non-earnings data published in financial reports is still largely unknown." In any case the preparation and use of accounting data could vary from country to country due to differences in economic activity. For example, while other countries use IAS, others use local standards.

In Kenya most of the financial institutions collapsed due to non-performing loans, Murugu (1998). This incidence of bad loans is worrying and put to question the credit models and quality of information employed by credit analyst. Net loans at the level of Shs. 215 billion as at December 31, 2001 accounted for 51\% of total net assets of Kenya's banking sector. At the same date the proportion of non-performing loans to total loans in Kenya was a high of $30 \%$. As at $31^{\text {st }}$ December 2001 non-performing loans amounted to Shs. 74 billion, Central Bank of Kenya Supervision Annual Report (2001). The rate of non-performing loans is changing due to law of natural selection and strict regulations on bank activities and much imposed supervision by Central Bank of Kenya, (Murugu, 1988). However, over the same period the ratio of advances to deposits stagnated, suggesting that commercial banks are skipping marginal borrowers.

Comparing, the ratio of non-performing loans to total loans (NPLs/TL) in Kenya of 33\% to similar African economies at the end of 2000, central banks of those countries (by then) reported that, this ratio (NPLs/TL) is much lower in Zimbabwe (24\%), Nigeria (11\%), and South Africa (3\%) (Central Bank Of Kenya Supervision Annual Reports, 2000). Again, this trend bring into focus the capacity of lending decision makers, the techniques that they employ and the quality of the input variables (e.g. quality of information contained in financial statements).

Annual report and accounts are audited and are readily obtainable, Coyle, (2000). Therefore the free rider theorem would suggest wider use of information contained in annual report. The annual report help analysts 
understand a firm's past, current situation, where it might be going, what factors affect it, and how this factors affect it, (Sharpe, Alexander and Bailey, 2004).

In Kenya, company's Act Cap 486, section 125 requires that every company make annual return to the Registrar of Companies. However the current companies act demand information that is highly aggregated. The act requires only a balance sheet; consequently any additional information contained in annual report is voluntary.

It is possible that to a lender, the most useful financial information source could be management accounts that consist of budgets and earnings forecasts. However, unlike annual accounts it is not easy for outsiders to get hold of management accounts or earnings forecast. Therefore, financial statements are relied on by financial analysts, Foster (1986), Coyle (2000).

The most important judge in firm valuation is the capital market. Stock prices are in actual fact one of the leading indicators for money and capital markets as a whole. However the Kenyan capital market is thin and only 54 companies are listed at the Nairobi Stock Exchange, at the time of finalizing this study (and 53 as at August 2007).

With the growing demand for information, there is a need to measure the level of satisfaction with the quality of information contained in annual reports. This study is on the perceived quality of information contained in financial statements as input to lending decisions. A number of studies on information sources have been carried out in the United States and the United Kingdom; and significant differences in the reported findings between these two countries. For example, where as reports from credit agencies and "Z" scores, Altman (1968) are widely used in the United States, Danos, Holt, and Imhoff (1989), but apparently little used in the United Kingdom (Berry et al., 1993). Not much is known about what is going on in Kenya.

An alternative motivation for this study is the emphasis on private interest as influencing the information to be included in annual report (Cooper and Sherer 2002). The private interest theory assertion is that shareholders interest dominates when it comes to deciding on contents of annual report. Therefore, it is necessary determining the extent to which the annual reports contain information useful to other users, such as credit analysts.

This study identify, areas where 'innovations' in external reporting lead to improved credit evaluation decisions, thus minimizing adverse selection problems such as loan processing costs, the bank's loan loss function, a reduction in loans made to clients that subsequently default, and an increase in loans made to clients that repay interest and principal in a timely manner.

\section{Research questions: -}

1. What constitutes a good lending objective(s)?

2. What are the sources of information for commercial banks when lending?

3. What is the extent to which different parts of financial statements are read?

4. What key additional information should be included in financial statements?

5. Which of the additional information should be incorporated in the company's act i.e. become a legal requirement?

\subsection{Literature Review}

In efficient markets, assets prices depend on demand and supply conditions. Such that if the demand exceeds supply, prices will rise, resulting into a decrease in demand or increased supply. This continues until an equilibrium price is attained (Stiglitz and Weiss, 1981). Credit rationing exists if the demand for funds exceeds its supply. In which case, the commercial banks must maximize return while minimizing risk on the advances. The major concern of the lender is the probability that the borrower will comply with the terms of loan agreement.

Foster (1986) identify the information sources that an analyst or a lender (e.g. commercial bank) could rely on as: talk to loan applicant; refer to lending institution files and personnel; external credit surveys; factor, labour and product markets; capital markets; and industry and economy and examine annual reports.

The US and UK evidence shows that bank managers rely on information derived from audited financials statements (usually for the past 3 years in order to assess the companies past record) Berry et al., (1993). The emphasis is placed on balance sheets, profit and loss accounts, notes to the accounts, auditor's report and directors'/chairman's report. Flow of funds statements were of variable importance Berry et al., (1993). The data collected is often put into banks in-house analysis sheets, which typically highlight key figures and financial ratios.

However the information collected and the weight attached to each information item varies according to the firm's size, the personal characteristics of the loan officer (e.g. age, qualifications) and the loan duration (Berry et al., 1991). The experience in small country like Kenya could be totally different.

Rouse (1989) summarize principles of good lending: character (the person), ability (to run the business), margin (bank risk reward), purpose (does the bank understand the business?), amount (is the loan amount adequate/excessive?), repayment (how does the bank get its money back?), and insurance (what is the security?). These variables can either be directly or indirectly derived from the financial statements.

The real risk in lending is to be found in the assessment of the repayment proposals, i.e. the probability of the borrower not meeting his/her obligations. The lender must establish the degree of certainty that the promised funds 
will be received. Where the source of repayment is income/cash flow, the lender will need projections from the borrower to ensure that there are surplus funds to cover repayment after meeting other commitments.

It is possible that with perfect information, lenders will not ask borrowers to provide security. The standards of lending must be satisfied irrespective of available security. Security is often considered necessary in case the repayment proposals fail to materialize. The sale of security is rarely as straight forward in practice as it appears in theory and security valuations often do not stand up to the ultimate test of realization. A game is said to have perfect information if all players know all moves that have taken place. As a result of supply of additional quality information, the importance of tangible security to UK bankers has diminished over time Berry et al, (1987). However, with the meltdown in US, it is likely that the importance of tangible security in lending decisions will be reviewed.

There are different sources of information. However, commercial banks are a privileged lot, in that they can order the applicant to supply past financial statements, projections of financial statement items (for example, cash flow), descriptions of the assets offered as collateral, and details of business plans and management experience.

For existing clients of the bank, information about the client's prior payment record, the track record of management of the firm applying for a loan, and so on may be readily available. Even if the applicant is a new client, information in the loan institution's files on "comparable firms" is useful in decision-making. This information can be processed in a heuristic way or via the development of a distress prediction model, a numerical scoring system, or a simulated computerized data analysis technique.

Factor, labour and product markets individually or collectively can be a rich information source. From such markets, information on the ability of a firm to retain the support of suppliers, customers and can be extracted. Issues relevant to evaluating loan application include the reliability of supply sources, the timing of wage contract negotiations, and the time trend of market share.

Information about the competitors of the client, as well as about the client itself, can be critical in predicting the ability of a loan applicant to make interest and principal repayments.

Capital market is an important source of information. By explicitly incorporating capital market information in the loan decision process, analysts can exploit two important features of efficient capital market: (a) its forwardlooking orientation and (b) its utilization of information from a broad spectrum of sources. Even if the applicant is not listed in the stock exchange, the loan analyst can still use capital market information supplied by comparable firms to gain insight about potential and existing borrowers.

Industry trade group forecasts, forecasts made by economists and reports from government departments and agencies about money supply, gross national production, and taxation are other important sources of information, (Fischer and Jordan, 1991).These information sources differ in several dimensions, and the challenge facing a loan analyst is to exploit these diverse information sources in a cost-effective and efficient way. Cohen, Gilmore, and Singer, (1966) present stages in the commercial lending process: Loan approval; loan monitoring; and loan termination.

Good understandings of the current loan decision-making process optimize resource management decision. An important area is the integration of financial statement information with other information. The latter includes strategy information on the firm applying for the loan, on its competitors and capital market information. For instance, strategy analysis could flag potential problems such as: loan applicant is currently profitable, but, need to make sizable investments in a new plant to remain profitable; and, loan applicant is experiencing rapid growth and high profitability that could be quickly eroded by a competitor's technological breakthrough; or even that the loan applicant is in profitable business but experiencing temporary cash flow difficulties.

Stein and Ziegler (1984) integrated assessments of the quality of management with balance sheet variables based on transactions made on the current bank account. They report that simultaneously combining sets of variables e.g. ratios "avoids deficiencies of using only one of the components and improves the early detection of credit risks".

Eldelstein (1975) explore how banks choose between potentially good and bad credit risks. Five characteristics are found to be the best statistical predictors: received his/her loan toward the chronological end of the survey period of the program; received a relatively large loan; had at least seven years of employment experience that was related to the type of business for which the loan had been sought; had accumulated a relatively large personal net worth (financial solvency and stability). Finally, the probability of successful loan repayment increased if a retail or wholesale business were located in a relatively low income; possibly due to the dense population within the ghettos.

The variables that appear to be important predictors of credit-worthiness in these previous studies are categorized into measures of financial performance, such as financial balance sheet data or financial ratios, and measures of stability/responsibility, such as the length of time employed.

Personal interviews and financial information are the main information sources in the bank lending decision Berry et al, (1993) and (Danos, Holt and Imhoff, 1989). The smaller the size of the firm the less important the financial information as it is perceived to be unreliable (Danos, Holt and Imhoff, 1989). Therefore, banks use 
personal interviews when evaluating loan proposals from smaller firms. Large firms tend to employ qualified accountants to produce more detailed and more frequent accounting information.

Stephens (1980) revealed that half of bank lending officers would refuse to loan to a company that did not submit financial statements, even though these might not be explicitly requested. Furthermore, banking systems demand for information show marked differences between countries Berry et al., (1993).

Danos, Holt and Imhoff, (1989) identify three phases in the lending process: Phase One: Gather background information about the borrower (e.g. company history and credit rating, location and type of business, number of employees, names of directors, key employees and owners). Credit ratings generally require three or five years past data and use the data to estimate loss curves; Phase Two: A location visit to "size up" the business to collect any missing data from phase one. This involves discussions with key employees regarding use of the loan and its repayment; Phase Three: Detailed financial information is collected (e.g. full accounts, budgets, and forecasts); an assessment of the organization and its ability to repay the loan is determined. The decision to make/not make the loan is then made.

Gibson (1983) reviewed how credit analysts in the United States use financial ratios derived from annual reports. Gibson (1983) sought commercial loan officers' views on what a specific ratio primarily measures, the significance (importance) of that particular ratio, and its frequency of inclusion in loan agreements. The three ratios rated as the most important were Debt/Equity, Current Ratio, and Cash Flow/Current Maturities of Long-Term Debt. The three ratios most likely to be included in loan agreements were indicated to be the Debt/Equity, Current Ratio, and Dividend Payout Ratio and Net profit margin (before and after tax) (Gibson,1983).

Backer (1970, p. 57) surveyed American loan officers and found lack of concern with subjective accounting methods, if there is full disclosure, that allow appropriate adjustments to financial statements. Zimmer (1979) found that loan officers rely greatly upon revenue recognition disclosures. Deitrick and Stamps (1981) established that loan officers adjust financial statements in line with "standard industry practice" or "appropriate to the circumstances".

Pike and Ross (1997) ranked the relative importance of the sources and types of credit information used by Canadian managers when assessing the risk of foreign buyers, and found that even for export sales, the primary focus of credit managers is on information about the buyer's credit character and financial strength, while political and economic risk information is generally of much less importance. Strangely, financial strength indicators were used less frequently than the other standard credit risk indicators-even though earlier studies show that credit managers perceive the buyer's financial strength as the most important factor in assessing creditworthiness, (Pike and Ross, 1997).

In the UK, 'traditional approaches' characterize the use of financial data by bank lending officers, (Otieno and Simon, 1999). McMonnie (1988) takes the view that user needs is a key determinant of form and content of financial reports; and that bank-lending officer (BLOs) is an important user group. McMonnie(1988) provide an all-embracing corporate reporting framework from a user perspective, this include disclosure of: forecast information, information on the economic environment and the human resources employed by the companies. The components in McMonnie (1988) considered in this study are: cash flow, assets, profit, future oriented information and non-financial information such as quantity measures of production.

Otieno and Simon, (1999) found firm profitability of importance to the BLO's. However, more emphasis is given to cash flows as a measure of business performance than the accountant's earnings. Key profitability indicators that BLO's used were gross and net profit margins. Otieno and Simon, (1999) found that the BLO's appreciated the distinction between profits generated from continuing operations and extraordinary items. McMonnie (1988) recommendations, which are reflected to a great extent in FRS 3, would be seen as sympathetic to the needs of BLO's. BLO's attempted to gain an understanding of the objectives of the loan applicant to assess the purpose of the loan.

Forecasts and plans when supplied by the loan applicants are relied on by BLO's. This includes cash flow forecasts on a monthly basis, for one or two years. When information was not supplied voluntarily it seems that BLO's did not specifically request the information. McMonnie (1988) and Otieno and Simon, (1999) suggest that more emphasis is given by BLO's to asset-values rather than to forecasts, i.e. that the banks are more concerned with security than the future cash generating ability of the business. This might be changing.

Although BLO's say they generally require an expanded information set within the framework of the financial reports, it was questionable as to the extent to which it would actually be used. It was found that the assessment of applications was much more impressionistic than analytical, (McMonnie, 1988).

In terms of cash flow statements, McMonnie (1988) recommendations have since been adopted through the Accounting Standards Board introduction of Financial Reporting Statement 1 (FRS 1) in 1991 and even form part of IAS's. Kenya uses IAS's. McMonnie (1988) dismisses historic cost valuations of assets in favor of net realizable value - an estimate of the amount the business would receive if an asset was sold, in an orderly fashion vis-à-vis in liquidation. The majority of the recommendations with regard to disclosure of profits have now been included in international accounting standards. 
A statement of corporate objectives is recommended so that performance can be judged in terms of the attainment of these objectives. In the case of forecast information, McMonnie(1988) recommends that a strategic plan and estimates of future cash flow should be disclosed. Disclosure of a firm's market, the rate of growth in that market and other economic information that affects firms within their environment is recommended. From the perspective of human resource accounting, McMonnie (1988) advocates disclosure of information related to the experience and accountability of influential officers of the company.

Beaver (1966) suggest the significance of cash flow information as predictor of bankruptcy. Beaver (1966) reported that cash flow from operations (CFFO), whose proxy measure is net income plus depreciation, depletion and amortization, to total debt had the lowest misclassification error relative to common accrual measures of financial health. These variables are derived from data contained in audited financial statements. Beaver's (1966) univariate approach to analyzing financial distress has limitation. For, example, while one ratio would indicate failure another could indicate non-failure. As an improvement to Beaver (1966), Altman (1968) use multiple discriminant analysis (MDA). Altman's (1968) MDA combines many financial ratios into an index that is used in classifying firms according to their financial performance. Deakin (1972) demonstrate the power MDA.

Bamber and Stratton (1997) find that when the loan application includes a modified audit report, bank loan officers classified the loan application as high risk and consequently asked for interest rate premium. These suggest that the uncertainty-modified audit report conveys information to bank loan officers.

Bamber and Stratton (1997) experimental results are consistent with a research survey of Miller, Reed and Strawser (1993)that imply that the expectation gap standards clarify the nature of the auditor's communication with financial statement users. These results do not support the opinion that the modified audit report is redundant. Rather, the results suggest that the auditor's additional disclosure of the uncertainty is informative because it provides an independent, informed second opinion about the level of the uncertainty. Munyeke (1996) concludes that the client's failure to supply audited or management accounts to the bank makes the monitoring exercise frustrating and even fruitless. Mucheke (2001) provides evidence of the additional need for loan recipients to make regular submission of financial data after the loan has been agreed.

\subsection{Methodology}

A structured questionnaire consisting of closed-ended questions is administered to all credit analysts in commercial banks in Kenya. At the time of the study, there were 43 commercial banks in total. The questionnaire covered: Lending objectives; Sources of information; Level of reading of different sections of financial statements; Additional information to be included in financial statements; Additional information to be incorporated in the Company's Act; and Background Information.

After items to be examined are generated and their form and response format decided, the instrument was reviewed and evaluated by colleagues within the accounting department to optimize the content validity of the instrument by carefully evaluating each item in the scale for relevance, clarity and closeness. The responses are first subjected to content validity tests, (Nunally and Bernstein, 1994).

The opinions or attitudes of the respondents were captured on a five points scale and the following scheme used to interpret the responses:

LABEL

For sections A, B, and D:

Very Important (VI)

Moderately Important

Slightly Important

Not Important

For Section C only:

Read Thoroughly (RT)

Read Briefly

Do not Read

\section{RANGE OF MEANS}

$$
\begin{array}{r}
3.5-4.49 \\
2.5-3.49 \\
1.5-2.49 \\
1.0-1.49 \\
2.5-3.00 \\
1.5-2.49 \\
1.0-1.49
\end{array}
$$
case, a variable with a score above average of 2.5 is considered important. The mean score for each variable score across respondents is calculated and used to rank the variables. The proposition is, the higher the mean the greater the importance of the item. Another representative measure to be used in this study is the mode. Standard deviation is used as a measure of spread or level of agreement among the respondents about the mean, Bowen and Weisberg (1980).

\subsection{Results and Discussions}

To establish the precision, consistency and stability of data capturing instrument, principal component analysis is used in establishing the relationship among variables. The standard measure of reliability in this study was Cronback's co-efficient alpha. The reliability co-efficient scores ranged between 0.81 and 0.94 with the overall 
reliability being 0.92 . The questionnaire content did not change much after the construct validity test.

A total of 27 questionnaires were received. This represents $63 \%$ response rate. The banks that responded held $95 \%$ of net assets within the banking industry. The respondents are well educated ( 87 percent were either graduates or postgraduates), and experienced (68 percent had more than five years experience in credit) and processed large volumes of loans (62 percent processed over Shs.300 million in a year). Eighty Five (85) percent of the respondents were between 26 and 45 years of old. Only 18 percent of the respondents were female, which is an indicator of low representation of women in this field.

\subsection{Objectives of the Lending Decisions}

Business objectives are things that a firm wants to achieve or accomplish over a defined period of time. These may be to earn profit for its growth and development, to provide quality goods to its customers, or even to protect the environment. It is believed that a business has a single objective, that is, to make profit. But making profit cannot be the only objective of business.

Table 1 Lending Objectives

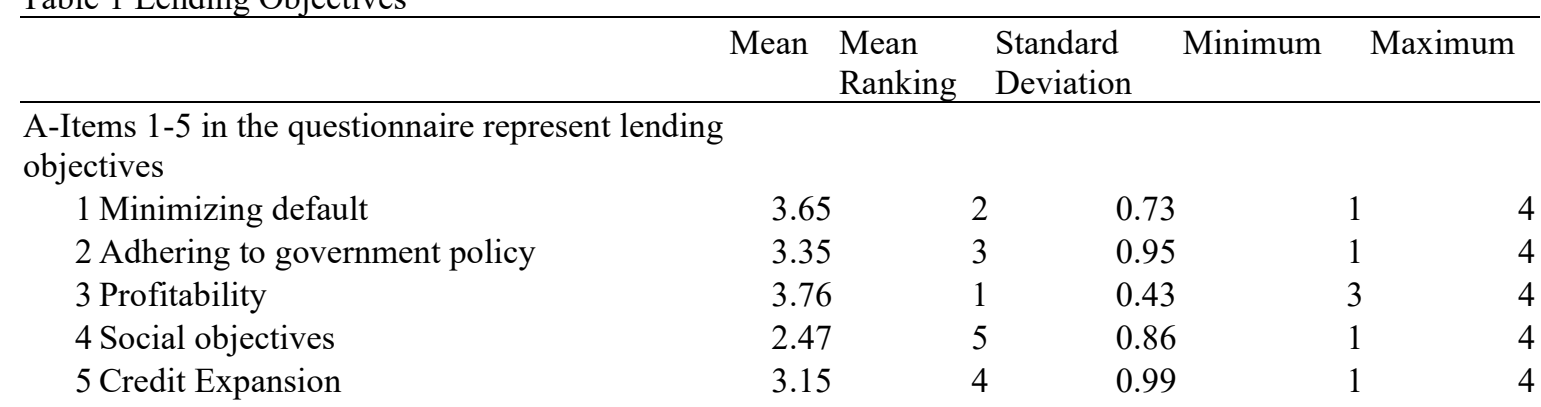

While pursuing the objective of earning profit, business units consider the interest of their owners. However, any business unit cannot ignore the interests of its employees, customers, the community, as well as the interests of society as a whole. The responses on lending objectives pursued by commercial banks are in table 1 above and table 2 below. With a standard deviation of less than one in all the categories of objectives, the respondents are generally in agreement about their lending objectives.

Profit making is the primary objective for which a business unit is brought into existence. Profitability ensures the survival of business firm, its growth and expansion. All respondents rank profitability as the most important objective with a rating score of 3 to 4 . Unprofitable business can survive in a competitive market.

Commercial banks are in business of making money while minimizing risk. The major banking problems continues to be directly related to sloppy credit standards for borrowers, poor portfolio risk management, or poor attention to changes in economic or other circumstances that impact adversely on the solvency and profitability of borrowers. The need to minimize default risk, with a mean of 3.65 is highly rated.

Adhering to government policy was highly ranked with a mean score of 3.35 and a modal score of 4 (very important). This high ranking is explained by the fact that failure to meet government policy requirements e.g. on cash ratio or minimum capital to be maintained by commercial banks is punishable.

Table 2 Frequency and Mode Value Labels

\begin{tabular}{lccccccc}
\hline & Not & Slightly & Moderately & Very & & & \\
& Important & Important & Important & Important & & \\
Value Label & 1 & 2 & 3 & 4 & Total & $\%$ Mode \\
\hline
\end{tabular}

Section A

1. Minimizing default

2. Adhering to government policy

3. Profitability

4. Social objectives

5. Credit Expansion

$\begin{array}{rr}3 \% & 6 \% \\ 6 \% & 15 \% \\ 0 \% & 0 \% \\ 15 \% & 32 \% \\ 9 \% & 15 \%\end{array}$

$\begin{array}{rrr}76 \% & 100 \% & 4 \\ 62 \% & 100 \% & 4 \\ 76 \% & 100 \% & 4 \\ 9 \% & 100 \% & 3 \\ 47 \% & 100 \% & 4\end{array}$

Social objectives are those objectives of a business that benefit of the society. Business operates in a society and utilizes its scarce resources. It is logical that the society expects something in return e.g. businesses can contribute towards the running of schools, hospital and colleges. The activities of the business should not be judged harmful to the society in order to avoid adverse public reaction. Social objectives of business comprise production and supply of quality goods and services, fair trade practices, controlling pollution and contribution to the general welfare of society. Respondents rated social objectives as only slightly important. This is characteristic of developing countries where many firms do not place a great amount of emphasis upon social objectives. A whole 
15 percent of respondents consider it 'not important', with a modal score of 3 (moderately important).

The extension of credit to customers is the bedrock of commercial banks business. The commercial bank managers should not shy from taking credit decisions. Again, to ensure that the bank's profitability do not suffer, their decisions must be based on quality information. Most of the respondents (57\%) consider credit expansion as not a very important objective. This is a shocker because commercial banks are not supposed to put their own interests ahead of the general financial climate. Commercial banks are expected to consolidate liquidity management, and to pay attention to changes in the capital market. In Kenya commercial banks loan fund to potential investors who are interested in initial public offer, thus increasing credit.

\subsection{Sources of Information}

An important element in many decisions is uncertainty. There may be, for instance, uncertainty over the future profitability of a firm, the quality of its management, or the ability of a borrower to fulfil obligations under a lending agreement. Respondents' opinion on eleven (11) different sources of information, considered useful in reducing uncertainty, is requested. This ranged from financial statements to newspapers, magazines and business journals. The responses are summarised in table 3 and 4 below.

Table 3: Sources of Information

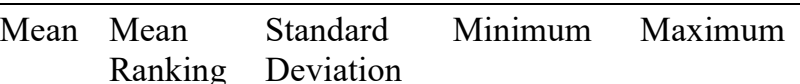

B-Items 6-16 in the questionnaire represent important sources of information

$\begin{array}{lrrrrr}\text { 6 Financial statements } & 3.85 & 1 & 0.36 & 3 & 4 \\ \text { 7 Customer's bankers } & 3.32 & 5 & 0.81 & 1 & 4 \\ \text { 8 Customer's employers } & 2.61 & 9 & 0.83 & 1 & 4 \\ \text { 9 Customer's references } & 3.06 & 6 & 0.89 & 1 & 4 \\ \text { 10 Customer's records with the lenders } & 3.82 & 2 & 0.46 & 2 & 4 \\ 11 \text { Customer's project proposal } & 3.70 & 4 & 0.59 & 2 & 4 \\ 12 \text { Credit rating agencies } & 2.38 & 10 & 1.05 & 1 & 4 \\ 13 \text { Visit to companies } & 3.76 & 3 & 0.50 & 2 & 4 \\ \text { 14 Government publications } & 2.82 & 7 & 0.87 & 1 & 4 \\ \text { 15 Tips And Rumours } & 2.18 & 11 & 1.03 & 1 & 4 \\ 16 \text { Newspapers, magazines and journals } & 2.77 & 8 & 0.86 & 1 & 4\end{array}$

Financial statements provide information useful to company officials as well as to various outsiders, such as investors, lenders of funds and tax authorities and regulators. Listed companies are required to periodically publish financial statements that include a balance sheet, an income statement, and a statement of cash flows. Financial statement as a source of information is rated by 85.29 percent of the respondents as very important, due to low cost. The result show that, none of the respondents ranked financial statements as not an important source of information (see table 4). This is consistent with the findings of Danos, Holt and Imhoff, (1989) in the U.S., Berry et al. (1993) in the U.K. and Otieno and Simon (1999) in Zimbabwe.

Financial statements information is one of many information sources that commercial banks rely on in their lending decisions. The second most highly ranked variable is customer's record with the lending institution. A customer with a good track record is unlikely to default on the next loan. The cost of using such records is relatively low. A visit to customer premises is also ranked as very important. Loan managers visit the business of borrowers to confirm whether the business actually exists and to see for themselves what goes on. 
Table 4: Sources of Information (Frequency Table)

Value Label

Section B Section B

6. Financial statements

7. Customer's bankers

8. Customer's employers

9. Customer's references

10. Customer's records with the lenders

11. Customer's project proposal

12. Credit rating agencies

13. Visit to companies

14. Government publications

15. Tips and rumours

16. Newspapers, magazines and journals

Slightly
Important
2

$0 \%$

$3 \%$

$9 \%$

$3 \%$

$0 \%$

$0 \%$

$26 \%$

$0 \%$

$6 \%$

$35 \%$

$9 \%$

Moderately
Important
3

Very

Important

4
Total Mode

$50 \%-100 \%$

$12 \% \quad 100 \% \quad 3$

$38 \% \quad 100 \% \quad 4$

$85 \% \quad 100 \% \quad 4$

$76 \% \quad 100 \% \quad 4$

$15 \% \quad 100 \% \quad 3$

$79 \% \quad 100 \% \quad 4$

$24 \% \quad 100 \% \quad 3$

$9 \% \quad 100 \% \quad 1 \& 3$

$50 \% \quad 18 \% \quad 100 \% \quad 3$

Customers' references, such as reports from customer's employer are slowly dying out because the probability of being supplied with a truly independent reference is generally too low. Customers will tend to appoint referees that they have good relationship with and who ultimately supply a biased report. However, commercial banks probably know a few other business owners who would supply correct information on a potential customer, thus the low rating of both the customer's reference and customer's employers as a source of information.

This study confirmed commercial banks concern about defaults. A business plan and a project proposal submitted along with application for a bank loan build a convincing case for the borrower's ability to put the amount borrowed to proper use and her ability to pay interest and repay the loan. Customer project proposal is ranked as very important. On studying a customer's project proposal, the lender can determine the intended use of the funds and the project's viability; and consequently the probability of default.

Customer's banker as a source of information is rated as moderately important. This suggests that credit risk analysts do not place too much reliance on this source. The reasons are that banks compete and are there fore reluctant to disclose information about their clients to their competitors; and that there are rules prohibiting a bank from disclosing information about a customer to nonaffiliated third parties, unless the institution satisfies various notice and opt-out requirements.

Newspapers, Magazines and trade journals are examples of external sources of information. Most industries in Kenya have at least one trade association that prepare trade publications on a regular basis. The publications reports data pertaining to industry it represents. Newspapers, magazines and journals as a source of information, is ranked position eight (8) i.e. fourth from bottom. This is because the quality of reporting in the trade publications is low. The quality is low because the managers are not willing to release information about their firms.

Credit rating agencies goal is to overcome asymmetric information between both market sides by evaluating financial claims according to standardized quality categories. These agencies are different from government in that they are part of the private certification industry. Credit rating agencies are rated very important in the United States, United Kingdom and Zimbabwe, Otieno and Simon (1999). Credit rating agencies are ranked as slightly important in Kenya, i.e. it is among the lowest with a mean of 2.38., probably due to lack of legislation to deal with issues of confidentiality of information given to credit rating agencies (Central Bank Of Kenya Supervision Annual Report, 1999) and local capacity inadequacy. In any case locally based rating agencies are at their infancy.

Tips and rumours have the lowest ranking suggesting that loan officers rarely use them. It is possible that banks are reluctant to accept that they rely on rumours or they consider this source less credible or that they find it difficult deriving meaning from rumours.

Government publications as a source of information are ranked as moderately important. This could be traced to the quality and reliability of information contained in such reports. In order for the government to get the most out of commercial banks, it must ensure a greater prospect for profitability and solvency for commercial banks by providing adequate infrastructure. The government is large enough to provide incentives for commercial banks to make up for the reduction of profitability on account of the credit information asymmetry and deficiency in collateral. Specifically the current government support for the establishment of comprehensive credit information is not good enough. A joint database of current and potential borrower information would benefit commercial banks and the banks customers because it would reduce the risk of lending to marginal borrowers; thus bring a 
larger number of entrepreneurs into the credit circuit.

Extent to Which Financial Statements Are Read

In Section B of the questionnaire responses (see items 6-16 of tables 3 and 4 above), it is noted that lenders (85.29 percent of the respondents) rely on financial statements in making lending decisions and they rate financial statements as a very important a source of information.

In Section C (see items 17-25 of table 5 below) we report respondents ranking of different parts of annual report. Respondents were asked to state the extent to which they read parts of the annual report. The assumption is that loan managers will read thoroughly those parts they relevant.

Table 5: Extent To Which Financial Statements Are Read

$\begin{array}{lllll}\text { Mean } & \begin{array}{l}\text { Mean } \\ \text { Ranking }\end{array} & \begin{array}{l}\text { Standard } \\ \text { Deviation }\end{array} & \text { Minimum } & \text { Maximum } \\ \end{array}$

C-Items 17-25 in the questionnaire represent the extent to which parts of financial statements are read

17 Balance sheet

18 Profit \& loss account

19 Statement of retained earnings

20 Cashflow statements

21 Notes to accounts

22 Director's report

23 Statement of accounting policies

24 Auditors' report

25 Chairman's report

3.94
3.97
3.59
3.82
3.56
2.85
3.11
3.68
2.65

2
5
3
6
8
7
4
9

0.24
0.17
0.70
0.46
0.66
0.86
0.84
0.59
0.85

$\begin{array}{ll}3 & 4 \\ 3 & 4 \\ 2 & 4 \\ 2 & 4 \\ 2 & 4 \\ 1 & 4 \\ 1 & 4 \\ 2 & 4 \\ 1 & 4\end{array}$
Altman (1968) shows that these models often use financial statements information. Dietrich and Kaplan (1982) developed a model designed to replicate the judgement used in classifying loan risk. By identifying the parts, which are thoroughly read and therefore important attempt to meet the information requirements is attainable.

The Profit and Loss Account, Balance Sheet and Cash Flow Statement with a mean of 3.97, 3.94 and 3.82 respectively are read thoroughly, which is consistent with the U.K. evidence, Berry et al. (1991) and the findings in Zimbabwe, Otieno and Simon (1999). The standard deviations of the items within this section are also low, i.e. below 1, suggesting that respondents agree on the extent to which parts of financial statements are read.

The Statement of Accounting Policies, the Notes to the Accounts, the Auditors' Report and the Directors' Report were read only briefly. Berry et al.(1993) found these components to be well read in the United Kingdom.

\subsection{Additional Information to Be Published In Financial Statements}

Credit analysts were asked to suggest additional information they wished to have included on financial statements. The results are summarised in table 6 below. 
Table 6: Additional Information To Be Published In Financial Statements

\begin{tabular}{lllll} 
Mean & Mean & Standard & Minimum & Maximum \\
& Ranking & Deviation & & \\
\hline
\end{tabular}

D-Items $25-42$ in the questionnaire relate to additional information to be published in the financial statements

$\begin{array}{lrrrrr}\text { 25 Business of directors } & 2.74 & 15 & 0.99 & 1 & 4 \\ \text { 26 Total remuneration of directors } & 2.65 & 17 & 0.85 & 1 & 4 \\ \text { 27 Research and development } & 2.79 & 14 & 0.89 & 1 & 4 \\ \text { 28 Change in top management } & 3.68 & 3 & 0.53 & 2 & 4 \\ \text { 29 Brand name } & 2.88 & 13 & 0.91 & 1 & 4 \\ \text { 30 Sales forecast } & 3.62 & 5 & 0.55 & 2 & 4 \\ \text { 31 Profit forecast } & 3.68 & 4 & 0.53 & 2 & 4 \\ \text { 32 Interim report } & 3.41 & 7 & 0.66 & 2 & 4 \\ \text { 33 Future earnings per share } & 2.65 & 18 & 0.85 & 1 & 4 \\ \text { 34 Market share } & 3.35 & 8 & 0.77 & 1 & 4 \\ \text { 35 Segmental reporting } & 2.94 & 12 & 0.81 & 1 & 4 \\ \text { 36 Actual paid tax } & 2.68 & 16 & 0.77 & 1 & 4 \\ \text { 37 Company products } & 3.12 & 10 & 0.95 & 1 & 4 \\ \text { 38 Turnover } & 3.77 & 2 & 0.61 & 1 & 4 \\ \text { 39 Management audit } & 3.24 & 9 & 0.86 & 1 & 4 \\ \text { 40 Cost of goods sold } & 3.44 & 6 & 0.71 & 1 & 4 \\ \text { 41 New product } & 2.97 & 11 & 0.85 & 1 & 4 \\ \text { 42 Cash flow statements } & 3.85 & 1 & 0.36 & 3 & 4\end{array}$

Cash flow statement, turnover, change in top management, profit forecast and sales forecast, in that order are all considered to be very important.

The major role for external reporting is to help investors to forecast a reporting entity's income. The difficulty with the forecast data is that forecasts are contingent on the future state of the world that the firms will be exposed to. Therefore some forecasts will be incorrect (Meeks, 1998).

Forecasting accounting variables such as turnover or profit, or even earnings per share mean predicting the value of such a variable. Forecasts tend to commit management to a future plan of action that act as a benchmark for performance evaluation. Management is reprimanded if the forecasts are significantly different from actual, even if the difference is positive because it shows that the reporting firms lack sufficient knowledge of their business.

Forecasting is equally beneficial to management. It enables management to review the organizations activities thus preventing losses through proper decision making. Shareholders scrutinize the companies that they invest in and subject such companies to results in the short term. The firm results are subject to scrutiny by investors and where the actual results differ from the forecasts, the stock prices are adversely affected, (Vadasz, 2007).

Statement of cash flows is a summary of a company's cash flows over a defined period of time (Gitman, 2006). It shows cash flows from: operation, investment, and financing activities. It is compiled using the data from income statement and balance. It indicates net increase or decrease in the cash and short term marketable securities for a given period, normally one year (Gitman, 2006). Cash flow statements and cash forecasts are useful in assessing the cash generated and used by the reporting entity and ultimately the debt capacity of the borrower. Cash flow related data help investors and lenders make informed decisions on both future investments and a firm's solvency.

The banks would like to see more information on change in top management form part of financial statements. This aspect relate to reporting of intellectual capital in corporate annual reports. Currently a framework on reporting changes in top management is lacking in Kenya. Just like in some developed countries, the key components of intellectual capital are poorly understood, inadequately identified, inefficiently managed, and not reported within a consistent framework when reported at all" (Guthie and Petty, 2000). When developed, we expect more firms to report much more on human capital (Abeysekera and Guthrie 2004). Reporting changes of management and their value to the firm highlight the impacts of such changes on firm value. 


\subsection{Additional Information to Be Incorporated in the Company's Act}

The issue of additional items to be incorporated in annual reports is actually a debate on the merits of self regulation, voluntary disclosure and government control. In this section we items to be included in the Company's Act (see table 7 below). This was to establish their level of comfort with voluntary disclosure Voluntary are disclosure in excess of requirement and "represent free choices on part of company management to provide accounting and other information deemed relevant to the decision needs of users of their annual reports, (Meek, Roberts and Gray, 1995).

Table 7: Additional Information To Be Incorporated in The Company's Act

\begin{tabular}{lllll} 
Mean & Mean & Standard & Minimum & Maximum \\
& Ranking & Deviation & & \\
\hline
\end{tabular}

E-Items 43-60 in the questionnaire relate to additional information to be incorporated in the Company's Act

\begin{tabular}{|c|c|c|c|c|}
\hline 43 Business interest of directors & 3.09 & 7 & 0.95 & 1 \\
\hline 44 Remuneration of directors & 2.73 & 15 & 0.94 & 1 \\
\hline 45 Research and development & 2.79 & 14 & 0.89 & 1 \\
\hline 46 Change in top management & 3.39 & 1 & 0.75 & 1 \\
\hline 47 Brand name & 2.88 & 12 & 0.93 & 1 \\
\hline 48 Sales forecast & 3.21 & 5 & 1.02 & 1 \\
\hline 49 Profit forecast & 3.24 & 4 & 1.00 & 1 \\
\hline 50 Interim reports & 3.03 & 10 & 0.85 & 1 \\
\hline 51 Future earnings per share & 2.61 & 18 & 1.03 & 1 \\
\hline 52 Market share & 3.00 & 11 & 1.03 & 1 \\
\hline 53 Segmental reporting & 2.67 & 17 & 0.89 & 1 \\
\hline 54 Actual tax paid & 2.73 & 16 & 0.91 & 1 \\
\hline 55 Company products & 3.06 & 9 & 1.06 & 1 \\
\hline 56 Turnover & 3.33 & 2 & 1.11 & 1 \\
\hline 57 Management audit & 3.15 & 6 & 0.97 & 1 \\
\hline 58 Cost of goods sold & 3.09 & 8 & 1.04 & 1 \\
\hline 59 New product & 2.88 & 13 & 0.96 & 1 \\
\hline 60 Cash flow statements & 3.33 & 3 & 1.11 & 1 \\
\hline
\end{tabular}

In table 7 above, a variable with a score above average of 2.5 is considered important for inclusion in the Company's Act. The variable with the highest mean is change in management and the lowest is future earnings per share. The standard deviation for items (sales forecast: 1.02, profit forecast: 1.00, turnover : 1.11, and cash flow : 1.11) are one or above one, suggest low level of agreement among respondents on their inclusion in annual reports.

Lenders considered change in top management, cash flow statement, turnover, profit forecast and sales forecast in that order of mean ranking as the most important additional items to be incorporated in the Company's Act. All items under this section were rated as being moderately important. A possible interpretation is the desire to have the Company's Act reviewed.

The additional disclosure requirement and other incorporation in Company Act well set users of financial information against suppliers of such information (management) and ownwes. In the past, the executives argued that they have to compare benefit of releasing additional information against the cost of providing such additional information and the adverse effects of disclosure on their competitive status, (Choi and Levich, 1990).

\subsection{Conclusions}

The assessment was to make inferences about commercial bank managers satisfactions with information contained in annual reports. It is useful to assess not only bank managers' perception of financial statements but also their perception on how to improve such statements. The results suggest that loan appraisal managers require more detailed information than is currently contained in the financial statements. Most of the respondents want firms to disclose detailed qualitative and quantitative information in their financial reports and would like some of the information incorporated in the company's act.

These findings are not significantly different from those of Otieno and Simon (1999) largely because the banking sector in Kenya and Zimbabwe are dominated by large multinational banks such as Barclays and Standard Chartered Bank. Secondly, the accounting practice does not differ much between Zimbabwe and Kenya. Again 
large audit firms with foreign connections dominate auditing sector.

Further Research

Future research should use in-depth interviewing techniques to provide a more complete picture of how credit risk analysts use financial statements in credit risk assessment in Kenya. It will also be useful determining the extent to which commercial bank in Kenya rely on capital market information when making lending decisions.

\section{REFERENCES}

Abeysekera, I., and Guthrie, J. (2004): "Human Capital in a Developing Nation", The British Accounting Review, Vol. 36, Issue 3, pp.251-268.

Altman, E. (1968): "Financial Ratios, Discriminant Analysis, and the Prediction of Corporate Bankruptcy". Journal of Finance (September): pp.589-609.

Backer, M. (1970): Financial Reporting for Security Investment and Credit Decisions. New York: National Association of Accountants.

Bamber, M.E., and Stratton R.A. (June 1997) "The information content of the uncertainty-modified audit report: Evidence from bank loan officers", Accounting Horizons.

Bank Supervision Annual Report, (2001):, A Central Bank of Kenya Publication.

Bank Supervision Annual Report,(2000) The Reserve Bank of Zimbabwe Publication.

Bank Supervision Annual Report,(2000) The Reserve Bank of South Africa Publication, 2000

Bank Supervision Annual Report,(2000): A Central Bank of Nigeria

Beaver, W.H.(1966): "Financial Ratios as Predictors of Failure", Journal of Accounting Research, pp.71-111.

Berry, A.J. Faulkner, S., Hughes, M., and Jarvis, R. (1993): "Financial Information, the Banker, and the Small Business". British Accounting Review 25 (2):131-150.

Bowen, B.D., and Weisberg, H.F. (1980): An introduction to Data Analysis. San Francisco: W.H. Freeman and Company.

Choi, F. D. S., and Levich, R. M. (1990): The Capital Market Effects of International Accounting Diversity, Homewood III, Dow Jones Irwin.'

Cohen, K.N.T.C., Gilmore and Singer, F.A., (1966): Analytical Methods in Banking, pp218 -249.

Cooper, D., Sherer, M.J. (1984), "The value of corporate accounting reports: arguments for a political economy of account", Accounting, Organizations and Society, Vol. 9 No.3/4, pp.207-32.

Coyle B., Corporate Credit Analysis, 2000.

Danos, P.,Holt, D.L., ABD Imhoff, E.A. (1989): "The Use of Accounting Information in Bank Lending Decisions", Accounting, Organisation and Society 14 (3): pp235-246.

Darwin C (1859) On the Origin of Species by Means of Natural Selection, or the Preservation of Favoured Races in the Struggle for Life John Murray, London; modern reprint Charles Darwin, Julian Huxley (2003).

Dietrich, J.R., and Kaplan, R.S.(1982): "Empirical Analysis of Commercial Loan Classification Decision," The Accounting Review (January): pp18-38.

Dietrick, J.W., and Stamps, J.L. (1981): "The Use of Accounting Information by Bank Loan Officers", Journal of Commercial Bank Lending November):pp51-62.

Eldelstein, R.H., (March, 1975) "Improving the Selection of Credit Risks: An Analysis of a Commercial Bank Minority Lending Program", The Journal of Finance Vol. XXX, No. 1.

Fischer, D. E., and Jordan, R.J. (1991): Security Analysis and Portfolio Management, Prentice Hall, Englewood Cliffs, New Jersey 07632, Fifth Edition.

Foster, G. (1973), 'Stock Market Reaction to Estimates of Earnings Per Share by Company Officials', Journal of Accounting Research (Spring 1973), pp. 25-37

Foster, George 1986. Financial Statement Analysis ( $2^{\text {nd }}$ edition): Prentice-Hall International.

Gibson, C. (1983): "Financial Ratios as Perceived by Commercial Loan Officers." Akron Business and Economic Review (summer): pp23-27.

Gitman, L.J. (2006). Principles Of Managerial Finance (1 $1^{\text {th }}$ ed). Boston, Massachusetts: Pearson Addison Wesley

Guthrie, J. and Petty, R. (2000): "Intellectual Capital: Australian Annual Reporting Practices" Journal of Intellectual Capital Vol. 1, Issue 3 pp. 241-251.

McMonnie, (1988): Making Corporate Reports Valuable, Published by the Chartered Institute of Accountants Scotland.

Meeks, G., (1998): "Profit Forecast In The Annual Report: The Problem of Economic. Assumptions". The British Accounting Review, Volume 30, Issue 2, pp. 159 - 172.

Meek, G. K., Roberts, C. B., Gray, S. J. (1995): "Factors Influencing Voluntary annual Report Disclosure by U.S., U.K, and continental European' Multinational Corporations". Journal of International Business Studies, Vol. 26.

Miller, J.R., Reed S.A., and Strawser R.H.,( 1993): “The information content of audit qualifications”, A Journal of Practice and Theory 11, pp69-82. 
Mucheke, J. 2002. Factors Contributing to Non-Performing Loans, Unpublished MBA Project.

Munyeke, Matata (1996): "Possible Causes of Poor Investment Portfolio: An Empirical Study Of Development in Financial Institutions in Kenya”, Unpublished MBA Project.

Murugu, J.K. (1998): "Bank Failure and Supervisory Response", Paper Presented to the $12^{\text {th }}$, East African Central Banking Course - Nairobi, Kenya.

Nunnally, J. C. and Bernstein, I. H. (1994) Psychometric theory. New York : McGraw-Hill.

Otieno O.L., and Simon J., (1999): “The Usefulness Of Annual Financial Statements", Research in Accounting in Emerging Economies.

Pike R.H. and Ross D.G., (1997) Trade Credit Information for Export Sales: The Canadian Experience,

Rouse, N., (1989): "Banker's Lending Techniques", The Chartered Institute of Bankers, Journal.

Sharpe, W., Alexander, G.J. and Bailey, J.V. (2004): Investments, Prentice Hall of India Limited

Stein, J.H.V. and Zeigler W., (June 1984):"The Prognosis and Surveillance of Risks from Commercial Credit Borrowers", Journal of Banking and Finance.

Stephens, R.G. (1980): Uses of Financial Information in Bank Lending Decisions, UMI Research Press 1980.

Stiglitz, J.E. and Weiss, A (1981): "Credit Rationing in Markets with Incomplete Information", American Economic Review 71(3) pp 393-410.

Vadasz, T (2007) “ Accurate forecasting” Sarbanes - Oxley Compliance Journal Website URL:http://www.s_ox.com/dsp_grtFeatureDetails.cfm?CID=6546

World Economic Forum Report (2015) "Accelerating Emerging Capital Markets Development Corporate Bond Markets" found at http://www3.weforum.org/docs/WEF Capital Markets Report 2015.pdf

Zimmer, I.R. (1979): "The Effect of Understanding on Attitudes to Accounting Variables", Accounting and Finance (November): pp15-22 